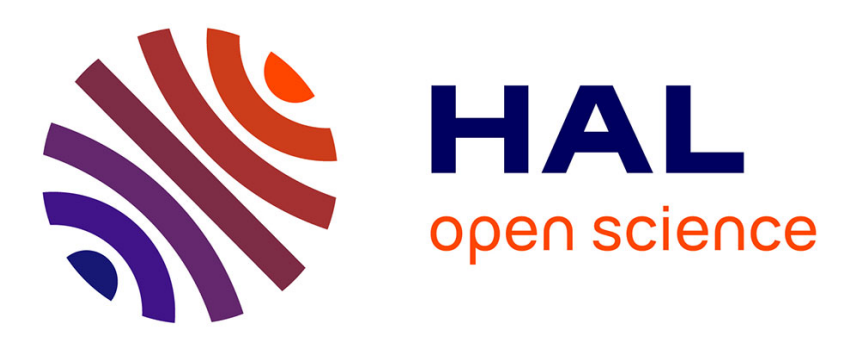

\title{
Use of AquaCrop model for estimating crop evapotranspiration and biomass production in hilly topography
}

N. Boudhina, M. M Masmoudi, Itidel Alaya, Frédéric Jacob, N. Ben Mechlia

\section{- To cite this version:}

N. Boudhina, M. M Masmoudi, Itidel Alaya, Frédéric Jacob, N. Ben Mechlia. Use of AquaCrop model for estimating crop evapotranspiration and biomass production in hilly topography. Arabian Journal of Geosciences, 2019, 12 (8), pp.259. 10.1007/s12517-019-4434-9 . hal-03520085

\section{HAL Id: hal-03520085 \\ https://hal.science/hal-03520085}

Submitted on 10 Jan 2022

HAL is a multi-disciplinary open access archive for the deposit and dissemination of scientific research documents, whether they are published or not. The documents may come from teaching and research institutions in France or abroad, or from public or private research centers.
L'archive ouverte pluridisciplinaire HAL, est destinée au dépôt et à la diffusion de documents scientifiques de niveau recherche, publiés ou non, émanant des établissements d'enseignement et de recherche français ou étrangers, des laboratoires publics ou privés. 


\title{
Use of AquaCrop model for estimating crop evapotranspiration and biomass production in hilly topography
}

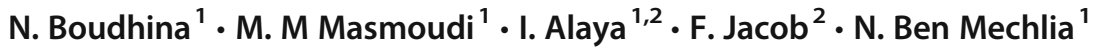

\begin{abstract}
The use of crop models in sloping areas is questionable when relief is not taken into account, as relief affects infiltration, radiation, and aerodynamic processes. The objective of this work is to evaluate the performance of FAO-AquaCrop model in simulating crop evapotranspiration, water balance, and biomass production in hilly areas using in situ measurements. The experiment was conducted in the Cap-Bon region, north-eastern Tunisia, on two wheat fields located on opposite sloping rims (A and B) and one control field (C) on a flat terrain: field A is SE-oriented with 5\% slope and B is NW-oriented with 6\% slope. Three flux stations were used to monitor automatically actual evapotranspiration (ET) and climatic factors whereas soil moisture and biomass production were measured manually. Model's outputs were compared to actual measurements using statistical indicators: slope of the regression line, root mean squared error (RMSE), and the coefficient of determination $\left(R^{2}\right)$. Actual ET varied between 1 and 2 mm during crop initial stage and 3$4 \mathrm{~mm}$ during mid-season stage. The ET/ETo ratio during mid-season was $0.81,0.74$, and 1.03 , respectively for fields $\mathrm{A}, \mathrm{B}$, and $\mathrm{C}$, well below the commonly used value of 1.15. Comparison between measured and simulated ET shows a substantial overestimation of the model in sloping fields with 6-20\% higher averages and a RMSE of $0.47-0.77 \mathrm{~mm} /$ day. AquaCrop seems to simulate reasonably well water balance, particularly in flat conditions. RMSE of water content in the top $100 \mathrm{~cm}$ soil-layer was in the range $41-67 \mathrm{~mm} / \mathrm{m}$, representing a relative error of $11-21 \%$. Simulated and measured biomass values presented similar trends $\left(R^{2}=0.86-0.94\right)$ with a systematic difference, indicating that AquaCrop outputs could be improved by a correction factor.
\end{abstract}

Keywords Crop evapotranspiration $\cdot$ Wheat $\cdot$ AquaCrop $\cdot$ Hilly terrain $\cdot$ Topography effect

\section{Introduction}

Fragility of agricultural hilly watersheds is likely to increase with intensification, climate change, and human pressure. In the context of a global warming, with a growing population and an increasing competition for water, the challenge for agriculture in south-Mediterranean regions is to increase water productivity (WP) in order to better use the scarce water resources. WP, defined as the ratio of crop biomass to crop

M. M Masmoudi

masmoudi.med@inat.agrinet.tn

1 INAT, University of Carthage, 43 av. Charles Nicolle, 1082 Tunis, Tunisia

2 IRD, UMR LISAH, 2 place Viala, 34060 Montpellier, France evapotranspiration (ET), combines two important and interrelated processes in agricultural systems, and it is an important indicator for measuring the quantitative relations between crop production and water consumption (Liu et al. 2007).

Actual evapotranspiration is used in crop yield simulation and water-resource applications, including irrigation scheduling. It is also used at larger scales in hydrological models and water resources planning and management as well as for climatic and ecological studies. Therefore, the temporal and spatial dimensions are important when accurate ET measurements and/or estimations are needed.

At field level, ET is the result of a complex interaction between soil-plant-atmosphere components and is the most difficult term of the water balance equation to measure and to estimate. Another difficulty appears when considering watershed levels. The spatial heterogeneity in the watershed impacts ET regime as it is the result of the interaction of local atmospheric factors, soil properties, and crop cover (Liu et al. 2012; Zhao and Liu 2014). 
According to Aguilar et al. (2010), the solar radiation that is the main variable of energy and mass transfer at the earth surface could have strong local gradients due to variability in slope and orientation. In the same context, Liu et al. (2012) reported a significant correlation between the spatial variation of radiation and wind patterns with aspect and elevation. The topography effects on energy and mass transfer could be neglected at regional scale but must be considered for accurate modeling at catchment and hill slope scales. This is especially the case of water fluxes in the Mediterranean region, characterized by heterogeneous landscapes and water scarcity. Examining the sensitivity of ET under Mediterranean climate conditions, Bois et al. (2008) noticed that the main factors impacting reference ET are solar radiation and wind speed.

Different crop models have been applied in the semi-arid/ sub-humid context of the Mediterranean to estimate biomass production and crop actual evapotranspiration, as a major term of land surface energy and water balances: STICS (Brisson et al. 2003), DSSAT (Jones et al. 2003), SAFYE (Duchemin et al. 2008), AquaCrop (Steduto et al. 2007) etc. For this study, the FAO-AquaCrop model is considered since it focuses on water and water productivity normalized for atmospheric evaporative demand and $\mathrm{CO}_{2}$ concentration that confer the model an extended extrapolation capacity, to diverse locations, seasons, and climate, including future climate scenarios. Besides, the green canopy cover used in AquaCrop can be related directly to easily accessible data from visual field observations and remote sensing such as vegetation indices which make the calibration and validation task over large areas easier (Foster et al. 2017).

Several authors reported on the accuracy of this model to estimate yield and biomass, e.g., Garcia-Vila et al. (2009) for cotton in Spain, Salemi et al. (2011) for winter wheat in the arid regions of Iran, and Araya et al. (2010) for barley in the semi-arid regions of Ethiopia. Yet, little is known about the estimation of the crop evapotranspiration within agricultural watershed typified by hilly topography, in spite of increasing evidence about the effect of relief on ET (Boudhina et al. 2018; Zitouna-Chebbi et al. 2012).

Although the effect of slope is considered in many models for estimating runoff and infiltration, the variability of evapotranspiration in relation to slope is not considered in most crop models using reference evapotranspiration and crop coefficient concepts. However, it is well established that air flow and aerodynamic properties of the boundary layer, which determine water vapor movement, are affected by slope and wind direction. Not taking into account topography in estimating actual evapotranspiration may result in errors on water budget and biomass production estimates.

The objective of this study is to assess the variability of ET, biomass, and soil water content during the crop cycle of wheat. The work was carried out in a hilly watershed of northern Tunisia using AquaCrop model (4.0) and field measurements. The model performance was evaluated using root mean square error (RMSE) and the coefficient of determination $\left(R^{2}\right)$.

\section{Materials and methods}

\section{Experimental site}

Experimental work was conducted in hilly region of Cap-Bon Peninsula, north-eastern Tunisia, on a small watershed: Kamech (36 $52^{\prime} \mathrm{N}, 10^{\circ} 52^{\prime} \mathrm{E}, 108 \mathrm{~m}$ a.s.1.). The area of the watershed is $2.6 \mathrm{~km}^{2}$ and a hilly dam $\left(145,000 \mathrm{~m}^{3}\right.$ capacity) was constructed in 1994 to promote irrigation in the area. The climate of the area is sub-humid Mediterranean. The average annual rainfall and ETo measured between 2004 and 2013 are respectively $620 \mathrm{~mm}$ and $1200 \mathrm{~mm}$ (OMERE observatory). The dry period occurs generally between June and August and the rainy season span from mid-September to mid-May.

Terrain elevation ranges from 100 to $200 \mathrm{~m}$ a.s.l and slopes range between 0 and 30\% (Ben Mechlia et al. 1998). The watershed soils developed into alternating sandstones and marls have variable textures that extend from clay to sandy loam. The soil depth is also highly variable and varies from a few millimeters to $2 \mathrm{~m}$. Agriculture is mainly rainfed, but very intensive with a large land fragmentation which lead to a high landscape heterogeneity (Mekki et al. 2006; Ben Mechlia et al. 2008). Cultivated crops are cereals (barley, oat, triticale, wheat) and legumes (chickpeas, fababean).

\section{Dataset and methodology}

In order to assess the effect of topography on AquaCrop performance in simulating water balance and biomass production, three experimental fields with different slopes and aspects are considered. The experiment was conducted on wheat during the growing season of 2013. Measurements of climatic factors, needed as input data for AquaCrop, and other variables, required for the model evaluation, i.e., crop evapotranspiration, soil moisture and biomass production, were carried out from January to May.

Climatic parameters and actual evapotranspiration were monitored in three wheat fields (A, B, and C) by three flux stations measuring energy fluxes and basic meteorological variables. Field (A) covers 1.2 ha area; it has a fairly homogeneous terrain slope $(6.0 \%)$ south-east oriented, versus dominant wind. Field (B) is adjacent to field (A), also with a homogeneous slope $(5.2 \%)$ oriented north-west, and has an area of 1 ha. Field (C) is a flat, 5 ha area, located in the south eastern part of the watershed. Fields $B$ and $C$ have both deep soils with fine texture (clay loam) and field A has a finer (clay) and deeper $(1.9 \mathrm{~m})$ soil. Hydraulic properties were estimated 
using the pedo-transfer functions and clay and sand proportions (Saxton and Rawls 2006). Measured percentages of sand and clay were used for fields $\mathrm{A}$ and $\mathrm{C}$ while only average values corresponding to its soil class were used for field $\mathrm{C}$. The estimated values of holding capacity and hydraulic conductivity at saturation were respectively 17,16 , and $20 \%$ and 26, 125, and $204 \mathrm{~mm} /$ day for A, B, and C. Crop and weather monitoring were made during vegetative crop cycle of wheat. For this study, we considered the period January-May 2013 covering the development to late season stages of wheat (Allen et al. 1998). For flux measurements, we focused on daytime measurements between 8:00 a.m. and 7:00 p.m., since night time values of sensible and latent heat fluxes are small at the daily time scale.

Reference evapotranspiration (ETo) was determined from meteorological measurements, according to the PenmanMonteith equation (Allen et al. 1998).

\section{Instrumental equipment and determination of latent heat flux}

Flux stations collected measurements of the land surface energy balance components (net radiation, soil heat flux, sensible and latent heat fluxes). Each station was equipped with a CR3000 data logger (Campbell Scientific). Sensible (H) and latent (LE) heat fluxes were determined using $20 \mathrm{~Hz}$ data of wind vertical velocity, temperature, and air humidity generated by sonic anemometers (CSAT3, Campbell Scientific) and Krypton hygrometers (KH20, Campbell Scientific). Net radiation $(\mathrm{Rn})$ and soil heat flux $(\mathrm{G})$ were measured by a differential radiometer (NR01, Hukesflux) and three soil heat flux sensors (HPF01, Hukesflux).

For each flux station, the three soil heat flux sensors were distributed few meters around the station and were buried at $5 \mathrm{~cm}$ below the soil surface; soil heat flux $(\mathrm{G})$ was estimated by averaging the measurements collected by the three soil heat flux sensors. The processing and quality assessment of data was detailed in the previous studies (Boudhina et al. 2017, 2018). With many missing data in the obtained time series, gap-filling method based on the LE/Rn ratio was used to derive daily ET values from hourly records, following the technique proposed by Roupsard et al. (2006).

\section{Crop and soil monitoring}

Vegetation has a key role in surface-atmosphere exchanges. The soil cover, height, and leaf area index directly influence these exchanges through aerodynamic resistance and surface resistance. It not only plays a leading role in evapotranspiration as a surface of exchange, but also in the roughness of the surface.
Monitoring of soil moisture and vegetation, i.e., crop height, biomass, and LAI, as well as phenology were conducted during the growing season for model evaluation.

The wheat phenology was monitored using Feekes scale. Fields A, B, and C depicted similar phenological evolutions. The beginning of tillering stage (stage 2) appeared on January 15 , and full tillering at stage 5 was on February 19. The end of stem elongation (stage 10) was on March 5, and flowering (stage 10.5.2) was on April 22. Ripening stage (stage 11) lasted from the beginning to the end of May, and the beginning of senescence (stage 11.4) was late May.

Vegetation height was measured on a weekly basis. For each date, an average of 30 plant height measurements was determined for each field. Vegetation height reached its maximum on April 22, and maximum averaged values were 1.00 $\mathrm{m}, 0.87 \mathrm{~m}$, and $0.98 \mathrm{~m}$, for fields $\mathrm{A}, \mathrm{B}$, and $\mathrm{C}$, respectively.

Green leaf area index (LAI) and biomass (dry matter) were measured biweekly for samples of 1-m long for three replicated plots. Maximum values of LAI were observed on April 11, and were $2.5,2.3$, and $2.3 \mathrm{~m}^{2} / \mathrm{m}^{2}$ respectively, for fields A, B, and $\mathrm{C}$.

Soil water content (SWC) was determined from soil moisture measurements by the gravimetric method with a weekly frequency. The number of soil profiles taken is three per field, located at the top, middle, and bottom of the field so that the variability of the soil and the slope is taken into account. Soil samples were taken in each profile every $0.10 \mathrm{~m}$ up to the depth of $1 \mathrm{~m}$.

\section{AquaCrop simulation model}

AquaCrop is crop water productivity model particularly suited to areas where water is a key limiting factor in crop production, especially in arid and semi-arid regions (Raes et al. 2009). The model simulates daily biomass production and final crop yield in relation to water supply and consumption and agronomic management, based on current plant physiological and soil water budgeting concepts. Therefore, the simulation of soil water balance and crop growth processes depend on crop, soil, weather, and management input data. The model deals with soil evaporation and crop transpiration as individual processes. The daily biomass accumulation is related to daily transpiration using a crop-specific water productivity parameter (WP*) normalized to climate evaporative demand (ET0) and $\mathrm{CO}_{2}$ atmospheric concentration. Harvestable yield is calculated from the above-ground biomass using a harvest index parameter that increases over the growing season and responds to water and temperature stresses. Details of the simulated processes are provided in a set of three papers which were published at the model's release (Steduto et al. 2009; Raes et al. 2009), in the Irrigation and Drainage Paper No. 66 "Crop Yield Response to Water" (Steduto et al. 2012), and in the reference manual (Raes et al. 2012) that is updated 
regularly. The AquaCrop model version used in this study is “Aquacrop 4.0"published in June 2012.

The crop parameters used here were adapted from a model calibration performed on wheat fields during four cropping seasons (2005-2009) in northern Tunisia (Sghaier et al. 2014), while in situ field observations and measurement were used for soil and weather parameters. The simulation was conducted for 2013 growing season using the measured climatic data (temperature, rainfall, and reference evapotranspiration) and soil properties in each field including depth and water retention characteristics.

\section{Results and discussion}

\section{Evapotranspiration}

Daily actual evapotranspiration of wheat measured by the eddy covariance method (EC) in each flux station during the development and mid-season stages is given in Fig. 1.

ET varies between 1 and $2 \mathrm{~mm}$ during tillering (JanuaryFebruary) and increased rapidly with crop development to reach 3-4 mm during mid-season stage (March). A decrease of ET level is observed from mid-April, as a result of lower soil water content (Fig. 3) and higher evaporative demand.

Comparison between ET estimated by FAO-crop coefficient method, by AquaCrop model, and field measurement was performed for each field, during the mid-season (Fig. 2). The ET/ETo ratio, representing empirically the FAO-crop coefficient Kc, during the mid-season stage (March 1-April 15 ), was determined for the three fields and was $0.81,0.74$, and 1.03 , respectively, for fields $\mathrm{A}, \mathrm{B}$, and $\mathrm{C}$, well below the commonly used value of 1.15 , proposed by the FAO-56 paper (Allen et al. 1998).

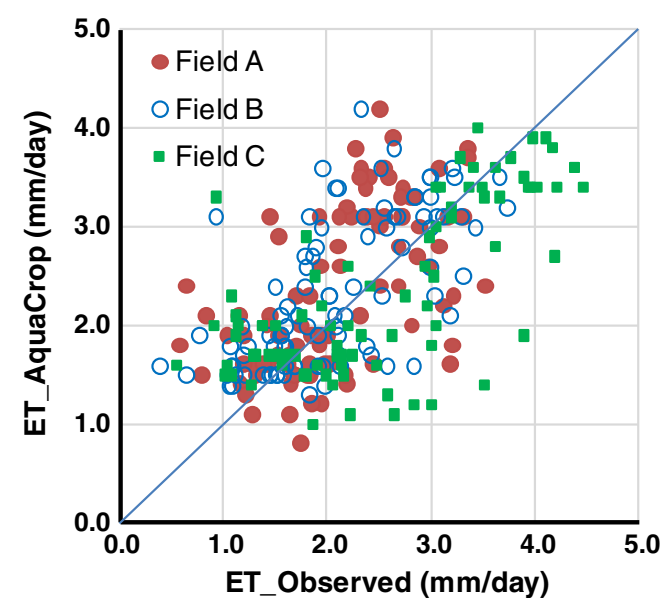

Fig. 2 Simulated vs measured actual evapotranspiration of wheat (ET) during the development-mid-season stages in three fields: A SE-oriented with $5 \%$ slope, B NW-oriented with $6 \%$ slope, and C flat field

Values of ET estimated by AquaCrop are coherent with those observed by eddy correlation (Fig. 2) with an overestimation for sloping fields. The slope of the regression line between measured values and those estimated by AquaCrop was 1.20 for field $\mathrm{A}$ and 1.06 for field B indicating 6-20\% higher averages compared to measured ET. Coefficient of determination $R^{2}$ is in the range $0.37-0.64$ (Table 1). RMSE range is between 0.47 and $0.77 \mathrm{~mm} /$ day.

The difference between measured and estimated values could also result from the measurement method. Several authors reported on cases of underestimation of ET by the EC method (Twine et al. 2000; Evett et al. 2012a, 2012b). In the present work, the difference between estimated and measured values is more important for SE-oriented field (A) than NWoriented field (B). The aerodynamic resistance, dependent on wind direction and field slope and aspect, may be the source of the observed difference between the three fields (Rana et al.
Fig. 1 Time course of measured actual evapotranspiration of wheat by the three flux stations during the development-midseason stages in three fields: A SE-oriented with $5 \%$ slope, B NW-oriented with $6 \%$ slope, and C flat field, January-May 2013

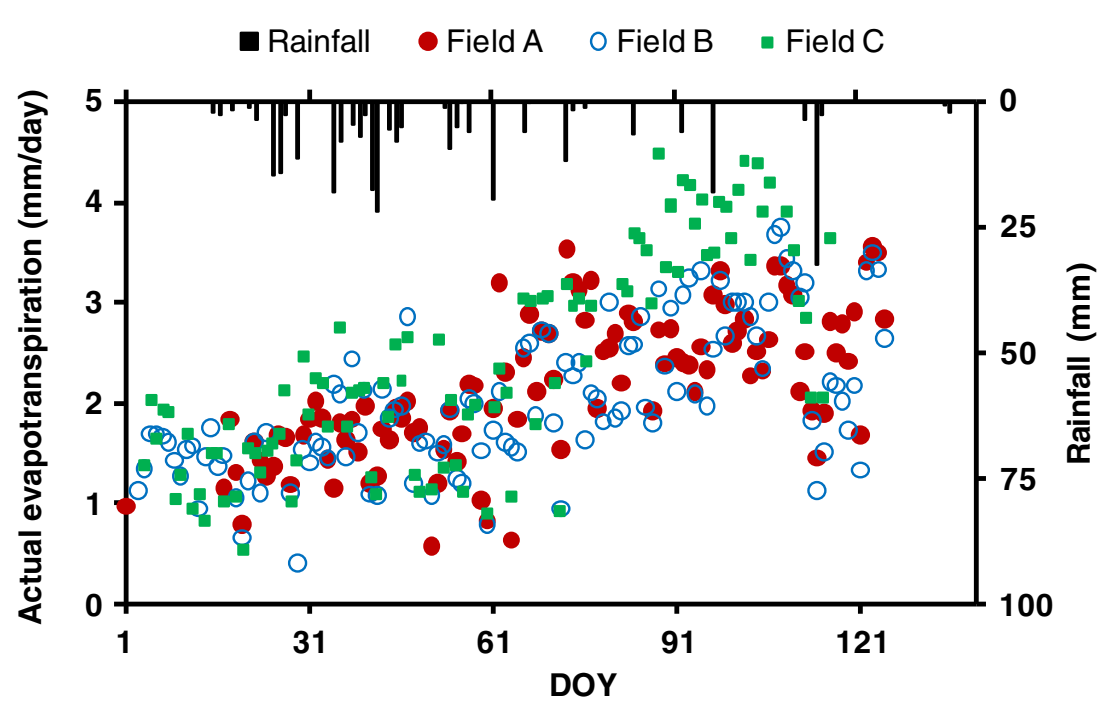


Table 1 Statistical performance indicators of AquaCrop model in simulating ET for three slope-aspect configurations: field A SE-oriented with $5 \%$ slope, B NE-oriented with $6 \%$ slope, and $\mathrm{C}$ flat field

\begin{tabular}{llll}
\hline ET & A & B & C \\
\hline Slope of the regression line & 1.20 & 1.06 & 0.94 \\
RMSE (mm/day) & 0.77 & 0.47 & 0.70 \\
$R^{2}$ & 0.39 & 0.64 & 0.37 \\
\hline
\end{tabular}

2007). Dominant direction during the experiment was NW with an average speed of $4 \mathrm{~ms}^{-1}$.

\section{Soil water content}

Soil water content (SWC) of the upper $100 \mathrm{~cm}$ was determined during the experimental period on weekly basis from soil moisture measurements (Fig. 3). The measured SWC is coherent with rainfall events and evapotranspiration level: it decreased gradually during January, as a result of water depletion and low amount of rainfall (only $6 \mathrm{~mm}$ during January 1-15).

From the last decade of January, SWC increased to field capacity following frequent rainfall events $(167 \mathrm{~mm})$, and soil moisture remained at high levels during development stage. Mid-season period was characterized by relatively stable and high levels of SWC in March despite the increasing ET (Fig. 1) which is compensated by $138-\mathrm{mm}$ rainfall. During April, SWC decreased rapidly as a result of lower rainfall amounts and higher evaporative demand (Fig. 3).

Comparison between measured and estimated values shows that AquaCrop simulates water balance relatively well, particularly for flat field C (Fig. 4). Coefficient of determination $R^{2}$ is 0.73 for field $\mathrm{C}$ and around 0.2 for sloping fields $\mathrm{A}$ and B (Table 2). RMSE varies between 41 and $67 \mathrm{~mm} / \mathrm{m}$, SWC is under-estimated by the model for sloping fields. The

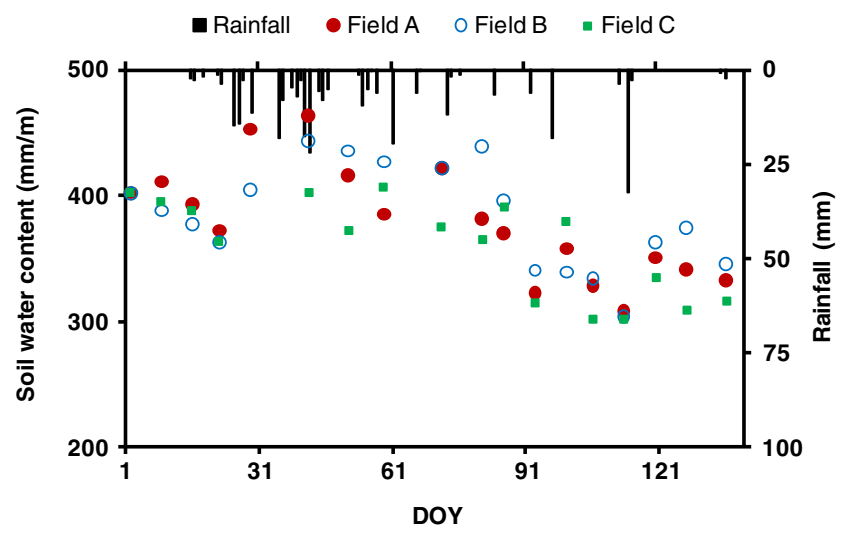

Fig. 3 Time course of measured soil water content of the upper $100 \mathrm{~cm}$ during the development-mid-season stages of wheat in three fields: field $\mathrm{A}$ is SE-oriented with $5 \%$ slope, B NW-oriented with $6 \%$ slope, and C flat field, January-May, 2013

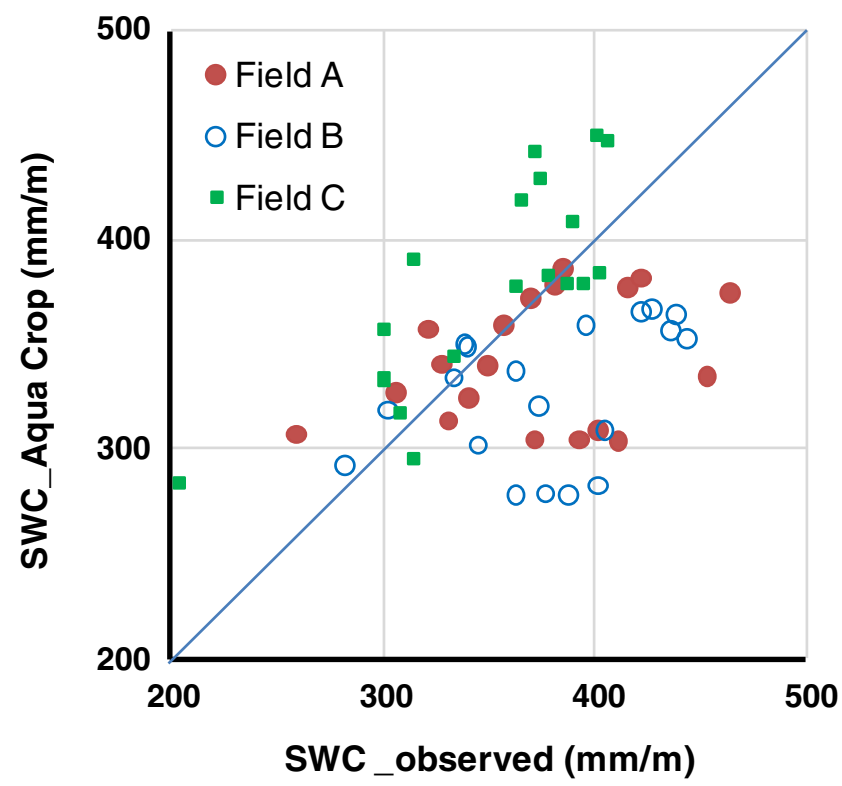

Fig. 4 Simulated vs observed soil water content (SWC) under wheat cultivation during the development-mid-season stages in three fields: A is SE-oriented with 5\% slope, B NW-oriented with $6 \%$ slope, and C flat field

deviation could be a result of the overestimation of ET and/or runoff module.

\section{Biomass}

The survey of above-ground biomass accumulated during the period January-May shows differences in crop development between the fields (Fig. 5). This disparity could be related to slight differences in the fields' characteristics but also to crop management.

Comparing the measured biomass with AquaCrop outputs, simulated results are in agreement with observed values in the three fields but with an overestimation for fields $\mathrm{A}$ and $\mathrm{C}$ and an underestimation for field B (Fig. 6).

Table 3 shows statistical indicators of performance; relatively high levels of $R^{2}(0.86-0.94)$, and the different values of the slope of the regression lines between measured and simulated biomass observed for the three fields indicate the possibility of adapting AquaCrop to take into account topography using a slope/aspect correction factor or a linear equation.

Table 2 Statistical performance indicators of AquaCop model in simulating water balance for three slope-aspect configurations: A SEoriented with $5 \%$ slope, B NW-oriented with $6 \%$ slope, and C flat field

\begin{tabular}{llll}
\hline SWC & A & B & C \\
\hline Slope of the regression line & 0.92 & 0.86 & 1.07 \\
RMSE $(\mathrm{mm} / \mathrm{m})$ & 55 & 67 & 41 \\
$R^{2}$ & 0.21 & 0.24 & 0.73 \\
\hline
\end{tabular}




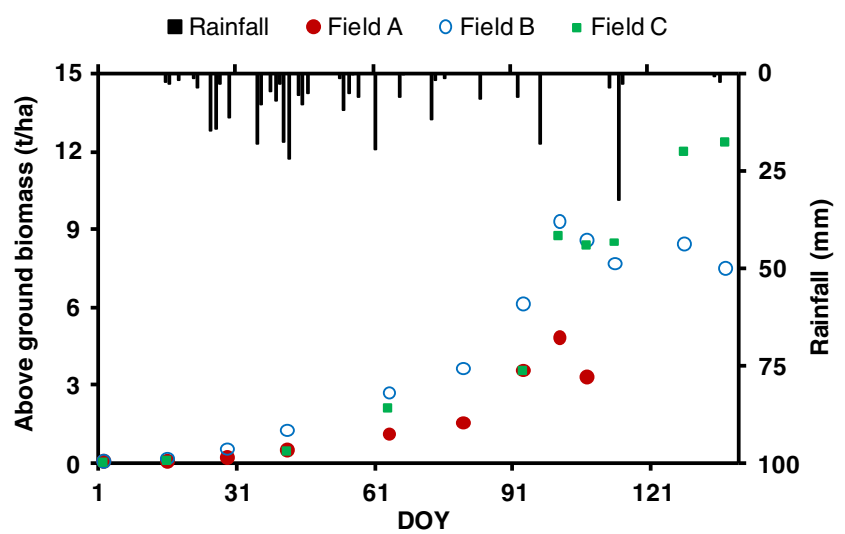

Fig. 5 Time course of measured above-ground biomass of wheat in three fields: field A is SE-oriented with 5\% slope, B NW-oriented with $6 \%$ slope, and C flat field, January-May 2013

\section{Conclusion}

Actual evapotranspiration is the main driver of biomass and water contents state variables in crop yield simulation models. However, ET is characterized by high spatial heterogeneity especially in hilly watersheds where topography may affects radiation and aerodynamic processes.

In this work, we evaluated the performance of FAOAquaCrop model for simulating wheat yield in a hilly topography. Data measured in three wheat fields with different configurations slope/aspect were used to evaluate the impact of relief on evapotranspiration, soil water content, and biomass and compare measured values to the model's output. The topography effects were detected by different values of the ratio ET/ETo representing the FAO-crop coefficient Kc. Results show coherence between simulated and observed values and

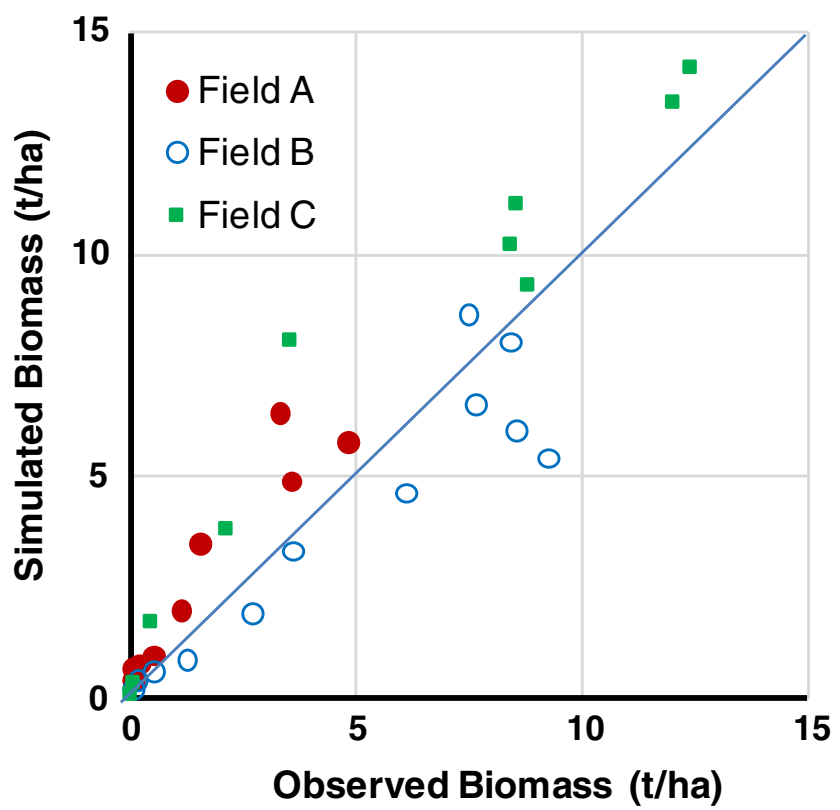

Fig. 6 Simulated vs measured above-ground biomass of wheat during the development-mid-stages seasons in three fields
Table 3 Statistical performance indicators of AquaCop model in simulating biomass accumulation for wheat crop under three slopeaspect configurations: A SE-oriented with 5\% slope, B NW-oriented with $6 \%$ slope, and $\mathrm{C}$ flat field

\begin{tabular}{llll}
\hline Biomass & A & B & C \\
\hline Slope of the regression line & 1.46 & 0.82 & 1.20 \\
RMSE(t/ha) & 1.39 & 1.52 & 2.04 \\
$R^{2}$ & 0.90 & 0.86 & 0.94 \\
\hline
\end{tabular}

differences between sloping and flat fields. The values of the experimental crop coefficient Kc during the well-watered mid-season stage (March 1-April 15) were respectively 0.81, 0.74, and 1.03 for $\mathrm{A}, \mathrm{B}$, and $\mathrm{C}$ fields, lower than the 1.15-1.20 range reported in the FAO paper 56. The lower rates of evapotranspiration observed in the sloping fields $\mathrm{A}$ and $\mathrm{B}$ affected water balance and biomass production modules and resulted in higher levels of simulated soil water content and contrasting biomass production.

The difference between fields A and B could be attributed to the orientation vs dominant wind and/or to the sensitivity of AquaCrop to soil texture since field A is fine textured compared to B and C. Errors in estimating ET seem to have a large impact on the results of the models because of the non-linear and dynamic nature of the interaction between evapotranspiration, soil water status, and biomass production variables. Adaptation of the model to take into account topography and wind direction for ET estimation is a necessity but needs more experimental work due to the interaction of the simulated processes and the multiplicity of sources of errors.

Funding information This study was financially supported by the French Institute of Research for Development (IRD), the National Institute of Agronomy of Tunisia (INAT) and the ANR-ALMIRA project.

\section{References}

Aguilar C, Herrero J, Polo MJ (2010) Topographic effects on solar radiation distribution in mountainous watersheds and their influence on reference evapotranspiration estimates at watershed scale. Hydrol Earth Syst Sci 14:2479-2494

Allen RG, Pereira LS, Raes D, Smith M (1998) Crop evapotranspirationguidelines for computing crop water requirements-FAO irrigation and drainage paper 56. FAO, Rome

Araya A, Habtu S, Hadgu KM, Kebede A, Dejene T (2010) Test of AquaCrop model in simulating biomass and yield of water deficient and irrigated barley (Hordeumvulgare). Agric Water Manag 97: 1838-1846

Ben Mechlia N, Mekki I, Zante P.(1998) Spatialisation de l'activité agricole et de l'occupation du sol dans une région au relief accidenté. in proc. of the int. symposium Satellite-based observation : a tool for the study of the Mediterranean basin. Tunis, 23-27 november 1998, CNES, France.

Ben-Mechlia N, Oweis T, Masmoudi MM, Mekki I, Ouessar M, Zante P, Zekri S (2008) Conjunctive use of rain and irrigation water from hill reservoirs for agriculture in Tunisia. ICARDA, Aleppo 
Bois B, Pieri P, Leeuwen CV, Wald L, Huard F, Gaudillere JP, Saur E (2008) Using remotely sensed solar radiation data for reference evapotranspiration estimation at a daily time step. Agric Forest Meteorol 148:619-630

Boudhina N, Masmoudi M M, Ben Mechlia N, Zitouna R, Mekki I, Prévot L, Jacob F (2017), Evapotranspiration of wheat in hilly topography : Results form measurement using a set of Eddy covariance stations. in M. Ouessar et al. (eds.) Water and Land Security in Drylands, pp. 67-76, Springer int. publ. AG 2017, https://doi.org/10. 1007/978-3-319-54021-4 7

Boudhina N, Masmoudi M M, Jacob F, Prévot L, Zitouna-chebbi R, Mekki I, Ben Mechlia N (2018). Measuring crop evapotranspiration over hilly area. in A. Kallel et al. (eds.), Recent Advances in Environmental Science from the Euro-Mediterranean and Surrounding Regions, Advances in Science, Technology \& Innovation, pp. 909-911, Springer int. Publ. AG 2018, https://doi. org/10.1007/978-3-319-70548-4_266

Brisson N, Gary C, Justes E, Roche R, Mary B, Ripoche D, Zimmer D, Sierra J, Bertuzzui P, Burger P, Bussiere F, Cabidoche YM, Cellier P, Debaeke P, Gaudillere JP, Maraux F, Seguin B, Sinoquet H (2003) An overview of the crop model STICS. Eur J Agron 18:309-332

Duchemin B, Maisongrande P, Boulet G, Benhadj I (2008) A simple algorithm for yield estimates: evaluation for semi-arid irrigated winter wheat monitored with green leaf area index. Environ Modell Softw 23:876-892

Evett SR, Howell TA, Baumhardt RL, Copeland KS (2012a) a. Can weighing lysimeter ET represent surrounding field ET well enough to test flux station measurements of daily and sub-daily ET? Adv. Water Res 50:79-90

Evett SR, Kustas WP, Gowda PH, Anderson MC, Prueger JH, Howell TA (2012b) b. Overview of the Bushland evapotranspiration and agricultural remote sensing experiment 2008 (BEAREX08): a field experiment evaluating methods for quantifying ET at multiple scales. Adv. Water Res 50:4-19

Foster T, Brozović N, Butler AP, Neale CMU, Raes D, Steduto P, Fereres E, Hsiao TC (2017) AquaCrop-OS: An open source version of FAO's crop water productivity model. Agric Water Manag 181: $18-22$

Garcia-Vila M, Fereres E, Mateos L, Orgaz F, Steduto P (2009) Deficit irrigation optimization of cotton with AquaCrop. Agron J 101:477487

Jones JW, Hoogenboom G, Porter CH, Boote KJ, Batchelor WD, Hunt LA, Wilkens PW, Singh U, Gijsman AJ, Ritchie JT (2003) DSSAT cropping system model. Europ J Agron 18:235-265

Liu J, Wiberg D, Zehnder A, Yang H (2007) Modeling the role of irrigation in winter wheat yield, crop water productivity, and production in China. Irrigation Sci 26:21-33

Liu M, Bárdossy A, Li J, Jiang Y (2012) Physically-based modeling of topographic effects on spatial evapotranspiration and soil moisture patterns through radiation and wind. Hydrol Earth Syst Sci 16:357373
Mekki I, Albergel J, Ben Mechlia N, Voltz M (2006) Assessment of overland flow variation and blue water production in a farmed semi-arid water harvesting catchment. Phys Chem Earth 31:10481061

Raes D, Steduto P, Hsiao TC, Fereres E (2009) Aquacrop the FAO-crop model to simulate yield response to water: I. Main algorithms and software description. Agron J 101:438-447

Raes D, Steduto P, Hsiao TC, Fereres E (2012) Calculation procedures. AquaCrop version 4.0. FAO land and water development division, Rome

Rana G, Ferrara RM, Martinelli N, Personnic P, Cellier P (2007) Estimating energy fluxes from sloping crops using standard agrometeorological measurements and topography. Agric For Meteorol 146:116-133

Roupsard O, Bonnefond JM, Irvine M, Berbigier P, Nouvellon Y, Dauzat J, Taga S, Hamel O, Jourdan C, Saint-André L, Mialet-Serra I, Labouisse JP, Epron D, Joffre R, Braconnier S, Rouzière A, Navarro M, Bouillet JP (2006) Partitioning energy and evapotranspiration above and below a tropical palm canopy. Agric For Meteorol 139:252-268

Salemi HMA, Lee TS, Mousavi SF, Ganji A, Yusoff MK (2011) Application of AquaCrop model in deficit irrigation management of Winter wheat in arid region. Af J Agric Res 610:2204-2215

Saxton KE, Rawls WJ (2006) Soil water characteristic estimates by texture and organic matter for hydrologic solutions. Soil Sci Soc Am J 70:1569-1578

Sghaier N, Masmoudi MM, Ben Mechlia N (2014) Paramétrage du modèle AquaCrop pour la simulation de la culture du blé dur. Revue des Régions Arides 35:1351-1360

Steduto P, Hsiao CT, Fereres E (2007) On the conservative behaviour of biomass water productivity. Irrigation Sci 25:189-207

Steduto P, Hsiao TC, Raes D, Fereres E (2009) Aqua-Crop the FAO crop model to simulate yield response to water: I. Concepts and underlying principles. Agron J 101:426-437

Steduto P, Hsiao TC, Fereres E, Raes D (2012) Crop yield response to water. FAO Irrigation and Drainage Paper, vol 66. FAO, Rome

Twine TE, Kustas WP, Norman JM, Cook DR, Houser PR, Meyers TP, Prueger JH, Starks PJ, Wesely ML (2000) Correcting eddycovariance flux underestimates over a grassland. Agric For Meteorol 103:279-300

Zhao X, Liu Y (2014) Relative contribution of the topographic influence on the triangle approach for evapotranspiration estimation over mountainous areas. Adv. Meteorol:1-16

Zitouna-Chebbi R, Prévot L, Jacob F, Mougou R, Voltz M (2012) Assessing the consistency of eddy covariance measurements under conditions of sloping topography within a hilly agricultural catchment. Agric For Meteorol 164:123-135 